\title{
Service Quality and Student Satisfaction: A Case Study at \\ Private Higher Education Institutions
}

\author{
Hishamuddin Fitri Abu Hasan \\ Research and Planning Department \\ Public Service Department of Malaysia \\ Federal Government Administrative Centre \\ 62510, F.T Putrajaya, Malaysia \\ Tel: 60-12-500-3429 E-mail: hishamfitri@jpa.gov.my
}

\author{
Azleen Ilias \\ Rahida Abd Rahman \\ Mohd Zulkeflee Abd Razak \\ School of International Business and Finance Labuan \\ Universiti Malaysia Sabah \\ Labuan International Campus \\ 87000, F.T Labuan, Malaysia \\ Tel: 60-87-460-517Ｅ-mail: neelza80@yahoo.co.uk
}

\begin{abstract}
This study attempts to examine the relationship between service quality dimensions and overall service quality (tangibility, responsiveness, reliability, assurance and empathy) and students satisfaction. Furthermore, this study is also examine critical factors in service quality dimensions (tangibility, responsiveness, reliability, assurance and empathy) that contributes most to the satisfaction of the students. This study was conducted using a set of questionnaire to 200 Bachelor Degree students from two private higher education institutions. The study will provide results from empirical test of these relationships. The empirical results of this study can provide support for the Parasuraman's SERVQUAL (1985), which related to the factors contributing to students' satisfaction.
\end{abstract}

Keywords: Service quality, SERVQUAL, Private higher education institutions.

\section{Introduction}

\subsection{Introduction}

In today's competitive academic environment where students have many options available to them, factors that enable educational institutions to attract and retain students should be seriously studied. Higher education institutions, which want to gain competitive edge in the future, may need to begin searching for effective and creative ways to attract, retain and foster stronger relationships with students. As a private organization, it has to depend on the interaction and mechanism of the market. As a result, competition to woo as many students as possible or so-called "potential customer" may become more and more intense. To make the matter harder, as a private institution, it does not have the "privilege" to receive any subsidies or financial assistances from the government (Teo, 2001).

An expectation that cannot be fulfilled on the institutions is the key factors for students' withdrawal (Alridge and Rowley, 2001). According to the study by Kanji, Abdul Malek and Wallace (1999) do give some insights on the real situation of the Higher Education Institutions in Malaysia. Most institutions do give a great deal of importance to meeting customers' expectations which is similar to business organization, but they still lack customer awareness among the staff, and it has become a common drawback for many institutions.

This bring us to an understanding that students will have more opportunity to support their continued enrollment into higher educational institutions and on how well the educational programs and services met students' expectations for services. In this competitive market, satisfaction with services may make the difference (Parasuraman, Zeithaml and 
Berry 1996). This study attempts to explore the aspects of service quality and the level of satisfaction among the students of private higher education institutions.

\subsection{Problem Statement}

Particularly in Malaysia, National Accreditation Body (LAN) once had to reject accreditation applications of 40 programs by private higher learning institutions due to the weaknesses in core course structures. Among factors that contributed toward the problems were the lecturers' lack of skills to handle the task and failure to attain the required curriculum standard set up by LAN (Mohd Feroz Abu Bakar, 2004).

The government for example has for long not compromising on the quality of education offered and hope to see that the private higher education will provide a quality education toward the students ("We won't compromise", 2001). This of course is in-synchronization with the current trend in education industry. Former Education Minister Tan Sri Musa Mohamad, has once made a statement regarding the weakness in the private HEI. According to him, he is aware there is a change of attitude among the present students nowadays as they are getting bolder in exercising their rights to demand for quality. One of his remarks on this issue is,

"Don't be surprised if a student takes one of you to court for not teaching properly."

(Rajah and Nadarajah, 2000).

In fact this is true as an issue on professionalism of an administration and the academic staffs of the private higher institution has been raised in one of the newspaper by the frustrated student due to his/her college misguided concern on issues like college reputation by "forcing" the students to involve in charitable activities that in the end overlook the bigger issue which is their academic performance ("Unprofessional College", 2004). This of course shows that students nowadays are indeed do not wait and see for the changes to be made but will put an effort to find an effective channels to voice their grievances if the management do not demonstrate that they care towards the complaints.

The intention here is obvious and well made but the problem is, comparing to the public higher education learning, it seems the perceptions of the people toward the private higher education tend to be biased in term of quality. It seems that the majority of students and parents especially Bumiputera place their hopes on public higher education institutions. If the students fail to be offered a place there, the perception is that he or she will have a bleak future. This is something that should not happen, as even the Prime Minister himself does not want these institutions to be the "last resort options" or a poorer alternative to public universities (Ling, 2003).

\subsection{Research Question}

RQ1: Determine the relationship between service quality dimensions and satisfaction among the students in two private higher institutions?

RQ2: What are critical factors in service quality that contribute most to the satisfaction of the students?

\subsection{Research Objectives}

Generally, the purpose of this study is to determine the relationship between service quality and student satisfaction in two private higher institutions. Several factors in service quality that will be discussed and analyzed are Tangibility, Assurance, Reliability, Responsiveness and Empathy.

The purpose of this research:

(1) To examine the relationship between service quality dimensions (tangibility, responsiveness, reliability, assurance, empathy and overall service quality) and students satisfaction

(2) To examine critical factors in service quality (tangibility, responsiveness, reliability, assurance and empathy) that contributes most to satisfaction.

\subsection{Significance of the Study}

Enhancing service quality has been demonstrated across numerous industries. The quality of service that can be applied to universities, especially to private universities, differentiates them from their public counterparts. Private HEI while attempting to compete at academic levels with other HEIs should offer an added advantage to champion quality services to their students. Notably, it can even be assumed to be an important road to the competitive excellence for the service oriented organization as by neglecting these aspects of quality services will put such organization at a competitive disadvantage compared to its counterparts because most of its revenues are enrollment related thus affecting its financial health (Zammuto et al., 1996). This study is important because it is going to measure the level of service quality and the level of satisfaction among the students as have been stressed by Iacobucci, Ostrom and Grayson (1995), "Presumably, if quality programs were initiated based on marketing research- that is, the changes were market driven and customer oriented- the quality improvements should lead to customer satisfaction" (p. 296). The result from the study can be used to give valuable information on the elements and the dimensions, which have been given a priority by 
students in assessing the quality of services and satisfaction. In addition to that, this study is going to provide the conclusions and some recommendations, which are hoped that it's going to provide useful information to the private higher education institutions.

\section{Literature}

\subsection{Student Satisfaction}

Kotler and Clarke (1987) define satisfaction as a state felt by a person who has experience performance or an outcome that fulfill his or her expectation. Satisfaction is a function of relative level of expectations and perceives performance. The expectation may go as far as before the students even enter the higher education, suggesting that it is important to the researchers to determine first what the students expect before entering the university (Palacio, Meneses and Perez, 2002). In contrary, Carey, Cambiano and De Vore (2002), believe that satisfaction actually covers issues of students' perception and experiences during the college years.

While most student satisfaction study focus on the perspective of customer, researchers is facing a problem of creating a standard definition for student satisfaction thus providing a need of customer satisfaction theory to be selected and modified so that it can explain the meaning of student satisfaction (Hom, 2002). Even though it is risky to view students as customer, but given the current atmosphere of higher education marketplace, there is a new moral prerogative that student have become "customer" and therefore can, as fee payers, reasonably demand that their views be heard and acted upon (William, 2002).

\subsection{Service Quality}

A definition of quality revolves around the idea that quality has to be judged on the assessment of the user or consumer of the service. The construct of quality as conceptualized in the services literature is based on the perceived quality. Perceived quality is defined as the consumer's judgment about an entity's overall experience or superiority (Zeithaml, 1987; Zammuto et al. 1996). Similarly, Parasuraman, Zeithaml and Berry (1990) also concluded that consumer perceptions of service quality result from comparing expectations prior to receiving the service, and their actual experience of the service. Perceived quality is also seen as a form of attitude, related to, but not the same as satisfaction, and resulting from a comparison of expectations with perceptions of performance (Rowley, 1996).

Therefore, perceived service quality could be the product of the evaluations of a number of service encounters and in this case, of a student, these could range from encounters with office staff, to encounters with tutors, lecturers, the head of departments, etc (Hill, 1995). As a result, if an organization regularly provides service at a level that exceeds customer expectations, the service will be evaluated as high quality. In contrast, if an organization fails to meet customer expectations, the service will be judge as poor quality (Zammuto et al., 1996).

Generally, students have three main criteria that need to be satisfied with services. These has been labeled as Requisite encounters which essentially enable students to fulfill their study obligations; Acceptable encounters which students acknowledge as being desirable but not essential during their course of study and Functional, an encounter of a practical or utilitarian nature (Oldfield and Baron, 2000).

According to Lassar, Manolis and Winsor (2000), two most prevalent and widely accepted perspectives on service quality include the SERVQUAL model and the Technical/Functional Quality framework. Gronroos (1984) held that service quality is made up of three dimensions "the technical quality of the outcome", "the functional quality of the encounter" and "the company corporate image". He argued that in examining the determinants of quality, it is necessary to differentiate between quality associated with the process of service delivery and quality associated with the outcome of service, judged by the consumer after the service is performed.

Parasuraman, Zeithaml and Berry (1985) however listed ten determinants of service quality that can be generalized to any type of service. The ten dimensions include tangibility, reliability, responsiveness, competence, access, courtesy, communication, credibility, security and understanding. In addition, these ten dimensions were then regrouped in the well-known five dimensions in the SERVQUAL model (Parasuraman et al., 1990) which include assurance, empathy, reliability, responsiveness and tangibility.

Previous research also done by Mahiah., S. et al. (2006) also confirmed Parasuraman, Zeithaml and Berry (1985) and they suggest that increasing of sophistication of reliability, empathy, tangibility, responsiveness and assurance can increase customer satisfaction towards services rendered by Human Resource department.

\subsection{Service Quality in Higher Education}

It is interesting to identify here about the applicability of SERVQUAL to education sector, meaning that there is a suitability of applying it in higher education. Numerous studies have adapted this measurement in HEI, such as SQ in business schools (Rigotti and Pitt, 1992) and higher educational institutions (Cuthbert, 1996; Soutar and McNeil, 1996; Saaditul, Samsinar and Wong, 2000). 
In the study by Cuthbert (1996) it has been found that among the dimension in SQ, the score for tangibility (3.34) is the highest, followed by assurance (3.21), reliable (3.11), responsive (3.04) and empathy (2.58). However he added that this does not represent tangibility as a major contributor towards satisfaction of the students as he believes it is the service encounter which is the determinant factor. O'Neill and Palmer (2004) also hold the exact same idea that, although tangibility is ranked as the best in term of overall performance score, but it has been ranked as the least importance by the students compared to process and empathy. Study by Perisau and McDaniel (1997) is best described as, assurance and reliability has been identified as the most important suggesting that students are most concern with the knowledge, courtesy and ability to inspire trust and confidence which is part of the assurance dimension.

Nevertheless, there are studies that have a different opinion on the importance of tangibility dimension in service quality. Smith and Ennew (2001) outlined an interesting aspect in his research toward the SQ in higher education. He highlighted that there is difficult aspect in the choice of satisfaction perception of customer between the affective indignation and the technical functionality. For example, the particular facility consumed by the students could be judged according to how reliable they are (technical functionality) or according to their ages, appearances, courtesy and empathy (affective). The perfect reliable facility, which is not up to date, but are capable of carrying out the task, may still be negatively rated if the users expect the university to provide up to date facility. He also showed that there were specific supportive items known as peripheral aspect and the university facilities, which students consume such as cafeterias and residential accommodation that will directly and indirectly have a significant impact on the evaluation of the university. Based on the study by Umbach and Porter (2002), it also appears that the size or a number of faculties within a department in HEI is important in explaining student satisfaction.

LeBlanc and Nguyen (1997) for example stressed on the reputation as a factor, which is tied closely to management's capacity to foster an organizational climate directed at serving the needs of its customers and to the image of the HEI. It is also process-related in that, it involves an ability to inspire trust and confidence and provide personal attention to students in a professional and caring manner. In term of importance, the study has shown that perceived value is derived mainly from price/quality, a factor that is closely tied to the business school's capacity to offer sufficient services to students and convince them that they are receiving quality services in exchange for what they give by means of their tuition fees.

While Ford, Joseph and Joseph (1999) go a little bit more specific on the services in their study about service quality by comparing the importance score of service quality in higher education for the New Zealand student sample and the United States sample. They found that for the New Zealand sample, academic reputation has been ranked as the first followed by career opportunities, programme issues, cost/time, physical aspects, location and others while for the USA sample, it was found that the first rank is academic reputation, cost/time, programme issues, others, physical aspects and choice influences.

Earlier researches on service quality in higher education also often emphasized academic more than administration, concentrating on effective course delivery mechanisms and the quality of courses and teaching (Atheeyaman, 1997; Cheng and Tam, 1997; Soutar and McNeil, 1996; Griemel-Fuhrmann and Geyer, 2003). However there are also an attempt to look upon the administrative side of higher institution like the study by Kamal and Ramzi (2002), which attempt to measure student perception of registration and academic advising across different faculties and other administrative services to assure positive quality service that compliments the academic.

\subsection{Service Quality and Students'Satisfaction}

Service Quality is commonly noted as a critical prerequisite for establishing and sustaining satisfying relationship with valued customers. In this way, the association between service quality and customer satisfaction has emerged as a topic of significant and strategic concern (Cronin and Taylor, 1992). In general, perceived service quality is an antecedent to satisfaction (Spreng and Mckoy, 1996). Thus, a proper understanding of the antecedents and determinants of customer satisfaction can be seen as to have an extraordinarily high monetary value for service organization in a competitive environment (Lassar, Manolis and Winsor, 2000).

Bigne, Moliner and Sanchez (2003) found that the overall service quality have a significant relationship with satisfaction at $\mathrm{R}=0.66$. Ham and Hayduk (2003) have confirmed that, even in the higher educational settings, there is a positive correlation between perception of service quality and student satisfaction, and analyzing upon the relationship based on each of the dimension of service quality, reliability $(\mathrm{R}=0.547$; sig. $=0.000)$ has the strongest relationship followed by responsiveness and empathy $(\mathrm{R}=0.5431$; sig. $=0.000)$, assurance $(\mathrm{R}=0.492$; sig. $=0.000)$ and tangibility $(\mathrm{R}=0.423$; sig. $=0.000)$.

Elliot and Shin (2002) found that the highly significant variables in the model that appear to directly impact overall customer satisfaction with university performance are: (1) excellence of instruction in major $(0.0522 ; p<0.0002)$, (2) able to get desired classes $(0.0935 ; \mathrm{p}<0.0000)$, (3) knowledgeable advisor $(0.0517 ; \mathrm{p}<0.0000)$, (4) knowledgeable faculty (0.0406; $\mathrm{p}<0.0094)$, (5) overall quality of instruction $(0.0510 ; \mathrm{p}<0.0000)$, (6) tuition paid is a worthwhile 
investment (0.0749; $\mathrm{p}<0.0000)$, (7) approachable advisor (9.0631; $\mathrm{p}<0.0000)$, (8) safe and secure campus (0.0646; $\mathrm{p}<0.0000)$, (9) clear and reasonable requirements for major $(0.0539 ; \mathrm{p}<0.0000),(10)$ availability of advisor $(0.0537$; $\mathrm{p}<0.0000)$, (11) adequate computer labs (0.0631; $<<0.0000)$, (12) fair and unbiased faculty $(0.0443 ; \mathrm{p}<0.0004)$, and (13) access to information $(-0.367 ; \mathrm{p}<0.0021)$.

\section{Methodology}

\subsection{Research Framework}

This study was adopted from Parasuraman's SERVQUAL dimensions. The dependent variable in this study is overall student satisfaction that is measured by the overall satisfaction with the HEIs. The independent variable in this study is service quality in higher education that measures the level of satisfaction with service performance. The dimensions included in this variable are tangibility, assurance, responsiveness, reliability, and empathy.

\subsection{Sample}

The samples in this study were bachelor degree students studying at a Private HEIs. For that purpose, directory from http://www.studymalaysia.com/jps/directori/senarai_ipts.shtml is use to identify the related private higher institutions that may serve as potential respondents. Respondent consists of Bachelor Degree students from Kuala Lumpur Infrastructure University College (KLiUC) and Kolej Universiti Teknologi dan Pengurusan Malaysia (KUTPM). We have distributed 230 questionnaires for every institution. Finally, 200 respondents completed and returned the questionnaires, which represents about $87 \%$ response rate.

\subsection{Instrumentation}

This study used questionnaire as a medium to obtain the data needed. There are three sections in the questionnaire, consisting of Section A: Demographic factor, Section B: Measurement of Service Quality in Higher Education and Section C: Measurement of Student Satisfaction. In this section A, four question covering from the subjects of gender, age, race or ethnicity, and their semester of study. Followed by section B: service quality in higher education and section C: student satisfaction. Instrument used in this research is adapted from Parasuraman et al. (1990) with some of the items used extracted from LeBlanc and Nguyen (1997) using the five dimensions in service quality (tangibility, assurance, reliability, responsiveness and empathy) using the Likert scale from 1 for not satisfied at all to 6 for very satisfied. In measuring student satisfaction, instrument for this variable was adapted from Atheeyaman (1997). In this variable, it has six items with Likert scale ranges from 1 for much worse than expected to 6 for much better than expected.

\subsection{Data Analysis Procedures}

The data analysis for this study conducted through 'Statistical Package for Social Science' software or SPSS version 12. The study also tested reliability of the instrument so that it enables to produce a robust and valid result.

\section{Findings}

\subsection{Profiles of the respondents}

The demographic information includes the following characteristic of participants: gender, age, semester of studies and ethnicity. The demographics information is represented in Table 1.1 based on frequency distributions and percentages.

From the 200 respondents in this study, 95 (47.5\%) are male and $105(52.5 \%)$ are females. The calculated mean age of the respondents is 23 years old with the majority of the students being 22 years old (33\%). Most of the respondents are in the fourth semester of their study $(28 \%)$, followed by fifth semester and above $(27 \%)$, second semester $(20 \%)$, third semester (14.5\%) and first semester (10.5\%). Majority of the respondents are Malay (72\%) followed by Chinese and Indian $(25 \%)$ and other ethnicity contributing about $3 \%$.

\subsection{Descriptive statistics of the variables in the model of the study}

For the dependent variable: student satisfaction contains of six items, while for the independent variable service quality, each of the dimension starting with tangibility contains 16 items, assurance 9 items, while reliability, responsiveness and empathy contains 7 items, totaling 46 items.

In Table 1.2, it shows that mean of student satisfaction was (4.17 on a 6-point scale) followed by service quality with an overall mean of 4.07 (on a 6-point scale). For each dimension, assurance scores the highest (4.44 on a 6-point scale), followed by responsiveness (4.09 on a 6-point scale), reliability (3.98 on a 6-point scale), tangibility and empathy (3.95 on a 6-point scale). The minimum score for student satisfaction is 1.00 indicating that there are students who felt that their satisfaction is much worse than expected and the maximum score is 6.00 indicating that there are some who felt that the satisfaction was much better than expected. As may seen in the Table 1.2 below, the mean for service quality is 4.07 , which can be perceived as students in these higher education institutions are actually somewhat satisfied with overall service quality. 
In Table 1.3, it can be seen that the highest mean score for item under an independent variables was "appearance of lecturers" (mean=4.89; $\mathrm{sd}=0.87$ ), followed by "friendly and courteous lecturers" $(4.76 ; 1.00)$ and "academic credentials of lecturers" $(4.77 ; 0.92)$ while the lowest score were "computers adequacy provided in the lab for students" $(3.27 ; 1.36)$ and "up-to-datedness of computers" $(3.38 ; 1.37)$ which mean that the lowest satisfaction toward the services was related to tangibility of services and the highest was related to assurance. However it can also be seen here tangibility item (appearance of lecturers) had the highest overall score. For the dependent variable (student satisfaction), the item "I am satisfied with my decision to attend this University" $(4.32 ; 0.99)$ score the highest while "If have a choice to do it all over again, I still will enroll in this University" $(3.94 ; 1.17)$ score the lowest.

\subsection{Reliability of the study}

Reliability coefficients of all variables included representing all dimensions for service quality presented in Table 1.4. All alpha coefficients are above 0.75. Previous research done by Mahiah., S. et al. (2006), support this study that seems this instruments quite reliable. For example tangibility dimension for this study (0.908) compared with Mahiah study (0.851), assurance is $0.887(0.917)$, reliability is $0.874(0.889)$, responsiveness is $0.854(0.919)$ and empathy is $0.881(0.886)$

\subsection{Relationship between Service Quality Determinants and Students'Satisfaction}

Table 1.5 indicate that there are significant and positive relationship between tangibility, assurance, reliability, responsiveness, and empathy and overall service quality to students' satisfaction. From the output, empathy has the strongest relationship with satisfaction followed by assurance, tangibility, responsiveness and reliability. The relationship between tangibility and student satisfaction is $\mathrm{r}=0.568$ meaning that tangibility has a moderate relationship toward satisfaction similar with assurance $(\mathrm{r}=0.582)$, reliability $(\mathrm{r}=0.555)$ and responsiveness $(\mathrm{r}=0.556)$. Only empathy show a stronger relationship with satisfaction with $\mathrm{r}=0.640$. The relationship between overall service quality and students' satisfaction is 0.653 meaning that the relationship is stronger than moderate. Furthermore, the results indicate that all the dimensions are highly correlated and very significant with one another. Therefore, the results proven that the service quality dimensions (tangibility, assurance, responsiveness, reliability and empathy) have a significant relationship with students' satisfaction. In fact, Mahiah., S. et al. (2006), shown that tangibility, empathy, reliability, responsiveness and assurance are highly correlated and very significant with one another.

\subsection{Critical factors in Service Quality}

In the Table 1.6, the results show that $\mathrm{R} 2=0.475$ (adjusted $\mathrm{R} 2=0.46$ ), meaning that $47.5 \%$ of the variance in students' satisfaction are explained by the five dimensions provided in the output. The $F$ statistics produced( $\mathrm{F}=29.102)$ is significant at the 0.000. From this result, tangibility (unstandardized coefficients $B$ is 0.175 at sign. $T=0.104$ ), responsiveness (unstandardized coefficients B is -0.004 at sign. $T=0.972$ ), and reliability (unstandardized coefficients B is -0.151 at sign. $\mathrm{T}=0.244$ ) are not significantly related with satisfaction.

From the results, it is apparent that two dimensions (empathy and assurance) are consistently more significant than the other dimensions (age, tangibility, responsiveness and reliability). It mean empathy and assurance are the two critical factors that contribute most to students' satisfaction. For assurance (unstandardized coefficients B is 0.406 at sign. T= 0.001 ) and empathy (unstandardized coefficients $\mathrm{B}$ is 0.498 at sign. $\mathrm{T}=0.000$ ) are significantly related with satisfaction.

\section{Discussion and Conclusion}

In this final section of the study, discussions on the important findings of the study will be reviewed in terms of its significance and support by other researches. This study attempts to examine the relationship between service quality dimensions (tangibility, responsiveness, reliability, assurance, empathy and overall service quality) and students satisfaction, and secondly to examine critical factors in service quality (tangibility, responsiveness, reliability, assurance and empathy) that contributes most to satisfaction.

\subsection{Discussion}

The Research Question 1 (RQ1) indicates five-service quality (tangibility, responsiveness, reliability, assurance and empathy) and overall service quality has strong relationship with students' satisfaction. The result is consistent with the finding by Ham and Hayduk (2003) and Bigne et al. (2003) that found there is a positive relationship between service quality and student satisfaction. In the study, empathy $(\mathrm{r}=0.640)$ has the strongest relationship followed by assurance $(\mathrm{r}=0.582)$, tangibility $(\mathrm{r}=0.568)$, responsiveness $(\mathrm{r}=0.555)$ and reliability $(\mathrm{r}=0.556)$. In addition, the relationship between overall service quality and students' satisfaction is 0.653 meaning that the relationship is stronger than moderate. Seeing that tangibility has a stronger relationship than responsiveness and reliability bring the researcher back to what Umbach and Porter (2002) have been stressing on earlier, seeing it as a compliment to the services provided in higher education in such to enhance satisfaction. Smith and Ennew (2001) also agree and the way they see it, the peripheral aspects and facilities will have a direct and indirect effect on the evaluation of higher institution. It is found that, although the dimensions in service quality are important but assurance is found to be one of the most important (Perisau and 
McDaniel, 1997). Consistent with what has been depicted by Soutar and McNiel (2003) in their research, stating that although all dimensions is service quality are actually useful in explaining student satisfaction, but that does not mean that all dimensions are significant. It proven that assurance is one of the dimensions that are significantly related with satisfaction meaning that students in higher institution are actually concern with the knowledge, courtesy and ability to inspire trust and confidence.

Cuthbert (1996), in his study has mentioned that the most important contributor to satisfaction is actually due to the service encounter. Soutar and McNeil (1997) also conclude the same opinion by seeing it from perspective of communication. This finding corresponds with Danielson (1998) found that when students expressed satisfaction with their college experiences, these situations seem to be centered on involvement and contact with people.

By sharing the same fundamental nature, it confirmed that empathy plays a crucial and an influential role toward satisfaction because referring back to the meaning of empathy; it defined as "being able to communicate care and understanding through the interpersonal skills of the staff and student-friendly policies and procedures". O'Neill and Palmer (2004) said empathy is a dimension that is significant with satisfaction, although the strongest support for this finding is actually from Maushart (2003) as he found that when student show a high satisfaction with their college experience, it is due to the formal and informal contact with their lecturer. It is understandable to the reason why the contact with the lecturers seem to play an important role because according to Clewes (2003) the process of teaching and learning is actually the central part to students' evaluation of service quality. It could have an effect toward students' evaluation on satisfaction. In this study, the Research Question 2 (RQ 2) indicates that assurance (unstandardized coefficients $\mathrm{B}$ is 0.406 at sign. $\mathrm{T}=0.001$ ) and empathy (unstandardized coefficients $\mathrm{B}$ is 0.498 at sign. $\mathrm{T}=0.000$ ) are significantly related with satisfaction are critical factors that contribute most to the satisfaction of the students.

\subsection{Conclusion}

From the results, it is clear that service quality has significant positive relationship with student satisfaction. Thus, it confirms what other literature try to suggest here, which is by improving service quality, it may potentially improve the students' satisfaction as well and that is the priority of the private higher institutions due to the fact that they have to compete to earn interest from the students to study there. It is important to verify here that from the regression analysis, two dimensions in service quality empathy and assurance are the most critical factor in explaining students' satisfaction. Whatever done to increase empathy and assurance in service quality therefore will help students to give better evaluation to their satisfaction.

\subsection{Limitation and Recommendation}

Service quality has been widely accepted as an antecedent of satisfaction and neglecting it may jeopardize the competitiveness of an organizations as satisfaction and competitiveness of a service related organizations are inter-related. For that, denying or neglecting the importance of service quality is the same like risking the continuation and the competitiveness of the institutions because by taking it into consideration service quality can actually explain almost $48 \%$ variance in satisfaction. More than that, by focusing on critical factor in service quality especially empathy and assurance mean that the institution is paving a way toward a better evaluation in satisfaction.

(1) One of the limitation in this study is to the context of respondents is very limited to only two private higher institutions that offered bachelor degree courses. As this private higher institutions do offer courses for the diploma and certificate courses, than it should be reasonable that they too are included in the future research.

(2) Further study is suggest to make a comparative study to investigate whether there are any differences in service quality and student satisfaction between public higher institutions and private higher institutions.

(3) Further study should also take serious consideration in terms of accessibility to the data collection because most of the institutions have been very reluctant in giving good cooperation. A serious preparation towards the unexpected situation is needed thus that it is in the ability researcher to face and in control of the situation.

\section{References}

Alridge, S., \& Rowley, J. (2001).Conducting a withdrawal survey. Quality in Higher Education, 7(1), 55-63.

Atheeyaman, A. (1997) Linking student satisfaction and service quality perceptions: the case of university education. European Journal of Marketing, 31(7), 528-540.

Bigne, E., Moliner, M. A., \& Sanchez, J. (2003). Perceived quality and satisfaction in multi service organizations: The case of Spanish public services. The Journal of Services Marketing, 17 (4), 420-442.

Carey, K., Cambiano, R. L. \& De Vore, J. B. (2002). Student to faculty satisfaction at a Midwestern university in the United States. HERDSA, 93-97. Retrieved August $28^{\text {th }}$ 2004, from www.ecu.edu.au/conferences/herdsa/main/papers/ref/pdf/ Carey.pdf

Cheng, Y. T., \& Tam, W. M. (1997). Multi-models of quality in education. Quality Assurance in Education, 5(1), $22-31$. 
Clewes, D. (2003). A Student-centred Conceptual Model of Service Quality in Higher Education. Quality in Higher Education, 9(1), 69-85.

Cronin, J. J. Jr., \& Taylor, S. A. (1992). Measuring service quality: a re-examination and extension. Journal of Marketing, 56, 55-68.

Cuthbert, P. F. (1996). Managing service quality in HE: is SERVQUAL the answer? Part 2. Managing Service Quality, 6(3), 31-35.

Danielson, C. (1998). Is satisfying college students the same as decreasing their dissatisfaction? AIR 1998 Annual Forum Paper. Paper presented at the Annual Forum of the Association for Institutional Research (38th, Minneapolis, MN, May 17-20, 1998), US Michigan.

Elliot, K. M., \& Shin, D. (2002). Student satisfaction: an alternative approach to assessing this important concept. Journal of Higher Education Policy and Management, 24(2), 197-209.

Ford, J. B., Joseph, M., \& Joseph, B. (1999). Importance-performance analysis as a strategic tool for service marketers: the case of service quality perceptions of business students in New Zealand and the USA. The Journal of Services Marketing, 13(2), 171-186.

Griemel-Fuhrmann, B., \& Geyer, A. (2003). Students' evaluation of teachers and instructional quality-analysis of relevant factors based on empirical evaluation research. Assessment \& Evaluation in Higher Education, 28 (3), $229-238$.

Gronroos, C. (1984). A service quality model and its marketing implications. European Journal of Marketing, 18(4), 36-44.

Ham, L., \& Hayduk, S. (2003). Gaining competitive advantages in higher education: analyzing the gap between expectations and perceptions of service quality. International Journal of Value-Based Management, 16 (3), $223-242$.

Hom, W. (2002). Applying Customer Satisfaction Theory to Community College Planning of of Student Services. IJournal. Retrieved January $7^{\text {th }} 2004$, from http://www.ijournal.us/ issue_02/ij_issue02WillardHom_01.htm

Iacobucci, D., Ostrom, A., \& Grayson, K. (1995).Distinguishing service quality and customer satisfaction: the voice of the consumer. Journal of Consumer Psychology, 4(3), 277-303.

Kamal Abouchedid, \& Ramzi Nasser (2002). Assuring quality service in higher education: registration and advising attitudes in a private university in Lebanon. Quality Assurance in Education, 10(4), 198-206.

Kanji, G. K., Abdul Malek bin A.Tambi, \& Wallace, W. (1999). A comparative study of quality practices in higher education institutions in the US and Malaysia. Total Quality Management, 10(3), 357-371.

Kotler, P., \& Clarke, R. N. (1987). Marketing for health care organizations. Englewood Cliffs, NJ: Prentice-Hall.

Lassar, W. M., Manolis, C., \& Winsor, R. D. (2000). Service quality perspectives and satisfaction in private banking, Journal of Service Marketing, 14 (3), 244-271.

LeBlanc, G., \& Nguyen, N. (1997). Searching for excellence in business education: an exploratory study of customer impressions of service quality. International Journal of Educational Management, 11(2), 72-79.

Ling, C. S. (April 09, 2003). Equal quality education' at private centers. New Strait Time - Management Times.

Mahiah., S., Suhaimi., S., \& Ibrahim., A.(2006). Measuring the level of customer satisfaction among employees of human Resource Division. Advances in Global Business Research 2006. Vol. 3. No.1. ISSN: 1549-9332.

Maushart, J. (December 4, 2003). Study says students are satisfied with college experience. The Daily Aztec, San Diego State U.

Mohd Feroz Abu Bakar (19 ${ }^{\text {th }}$ October 2004). LAN tolak 40 program IPTS. Berita Harian, 3.

O’Neill, M. (2003). The influence of time on student perceptions of service quality: The need for longitudinal measures, Journal of Educational Administration, 41(3), 310-324.

Oldfield, B. M. \& Baron, S. (2000). Students perception of service quality in a UK university business and management faculty. Quality Assurance in Education, 8 (2), 85-95.

O'Neill, M. A., \& Palmer, A. (2004). Importance-performance analysis: a useful tool for directing continuous quality improvement in higher education. Quality Assurance in Education, 12(1), 39-52.

Palacio, A. B., Meneses, G. D. \& Perez, P. J. P. (2002).The configuration of the university image and its relationship with the satisfaction of students. Journal of Educational Administration, 40(5), 486-505.

Parasuraman, A., Zeithaml, V. A., \& Berry, L. L (1996). The behavioral consequences of service quality. Journal of Marketing, 60(2), 31-46.

Parasuraman, A., Zeithaml, V. A. \& Berry, L. L. (1990). Five imperatives for improving service quality. Sloan 
Management Review, 29-38.

Parasuraman, A., Zeithaml, V. A., \& Berry, L. L. (1985). A conceptual model of service quality and its implications for future research. Journal of Marketing, 49, 41-50.

Parasuraman, A., Zeithaml, V., \& Berry, L. (1988). SERVQUAL: a multiple item scale for measuring consumer perceptions of service quality. Journal of Retailing, 6(1), 12-36.

Perisau S. E., \& McDaniel, J. R. (1996). Assessing service quality in schools of business. International Journal of Quality and Reliability Management, 14(3), 204-218.

Rajah, D., \& Nadarajah, V. (August 8th, 2000). Go for quality: Musa suggests methods for varsities to improve, New Strait Time, 1 .

Rowley, J. E. (1996).Customer compatibility management: an alternative perspective on student-to-student support in higher education. International Journal of Educational Management, 10(4), 15-20.

Saaditul Ibrahim, Shamsinar Md SIdin \& Wong Chee Meng (2000). Customer satisfaction towards service quality of higher education in Malaysia. Seminar FEP 2000 Pulau Pinang, 20 - 23 October 2000. Retrieved November $9^{\text {th }}, 2004$, from http://www.econ.upm.edu.my/ repport/mgm11b.html.

Sekaran, U. (1992). Research method for business: A skill building approach. New York: John Wiley \& Sons Inc.

Smith, R. \& Ennew, C. (2001, January). Service quality and its impact on word of mouth communication in higher education. Online: http://www.unim. nottingham.ac.uk/dbm/papers/ 2001-01.pdf. on $15^{\text {th }}$ September 2004.

Solomon, M. R. (1996). Consumer behavior. Englewood Cliffs, NJ: Prentice-Hall.

Soutar, G. \& McNeil, M. (1996). measuring service quality in a tertiary institution. Journal of Educational Administration, 34(1), 72-82.

Spreng, R. A. \& Mackoy, R. D. (1996). An empirical examination of a model of perceived service quality and satisfaction, Journal of Retailing, 72(2), 52-64.

Teo, C. L. (October $21^{\text {st }}$ 2001). Realities of private institution. New Strait Time, 4.

Umbach, P. D. \& Porter, S. R. (2002). How do academic departments impact student satisfaction? Understanding the contextual effects of departments. Research in Higher Education, 43(2), 209 - 234.

Unprofessional College. (2004, November $\left.1^{\text {st }}\right)$. Harian Metro, 11.

We won't compromise on quality of private higher education, says Hon. (April 02 $2^{\text {nd }}, 2001$ ). New Strait Time, 4.

William, J. (2002). The student satisfaction approach: student feedback and its potential role in quality assessment and enhancement. 24 ${ }^{\text {th }}$ EAIR Forum, Prague, 8-11 September.

Zammuto, R. F., Keaveney, S. M. \& O'connor, E. J. (1996). Rethinking student services: assessing and improving service quality. Journal of Marketing in Higher Education, 7(1), 45-69.

Zeithaml, V. (1987). Defining and relating price, perceived quality and perceived value. Cambridge, MA: Marketing Science Institute. 
Table 1.1 Profile of Respondents

\begin{tabular}{|c|c|c|}
\hline Variables & Frequency (n) & Percentage (\%) \\
\hline \multicolumn{3}{|l|}{ Gender } \\
\hline Male & 95 & $47.5 \%$ \\
\hline Female & 105 & $52.5 \%$ \\
\hline \multicolumn{3}{|l|}{ Age } \\
\hline 21 & 40 & $20.0 \%$ \\
\hline 22 & 66 & $33.0 \%$ \\
\hline 23 & 63 & $31.5 \%$ \\
\hline 24 & 20 & $10.0 \%$ \\
\hline 25 & 6 & $3.0 \%$ \\
\hline 26 & 2 & $1.0 \%$ \\
\hline 28 & 2 & $1.0 \%$ \\
\hline 29 & 1 & $0.5 \%$ \\
\hline \multicolumn{3}{|l|}{ Mean age $=22.54$} \\
\hline \multicolumn{3}{|l|}{ Ethnicity } \\
\hline Malay & 144 & $72.0 \%$ \\
\hline Chinese & 25 & $12.5 \%$ \\
\hline Indian & 25 & $12.5 \%$ \\
\hline Others & 6 & $3.0 \%$ \\
\hline \multicolumn{3}{|l|}{ Semester } \\
\hline First Semester & 21 & $10.5 \%$ \\
\hline Second Semester & 40 & $20.0 \%$ \\
\hline Third Semester & 29 & $14.5 \%$ \\
\hline Fourth Semester & 56 & $28.0 \%$ \\
\hline Fifth and Above & 54 & $27.0 \%$ \\
\hline
\end{tabular}

Table 1.2 Descriptive Statistics of Measures

\begin{tabular}{|l|l|l|l|l|l|l|}
\hline Variable Type & Variable Name & N & $\begin{array}{l}\text { No. of } \\
\text { item }\end{array}$ & $\begin{array}{l}\text { Minimum } \\
\text { Score }\end{array}$ & $\begin{array}{l}\text { Maximum } \\
\text { Score }\end{array}$ & $\begin{array}{l}\text { Actual } \\
\text { Means }\end{array}$ \\
\hline Dependent Y & Student Satisfaction & 200 & 6 & 1.00 & 6.00 & 4.17 \\
\hline Independent & & & & & & \\
Service Quality & & & & & & \\
X1 & Tangibility & 200 & 16 & 2.25 & 6.00 & 3.95 \\
X2 & Assurance & 200 & 9 & 1.25 & 6.00 & 4.44 \\
X3 & Reliability & 200 & 7 & 1.43 & 6.00 & 3.98 \\
X4 & Responsiveness & 200 & 7 & 1.43 & 6.00 & 4.09 \\
X5 & Empathy & 200 & 7 & 1.71 & 6.00 & 3.95 \\
\hline
\end{tabular}


Table 1.3 Questionnaire items

\begin{tabular}{|c|c|c|c|}
\hline & Question & Mean & $\begin{array}{l}\text { Standard } \\
\text { Deviation }\end{array}$ \\
\hline & Service Quality (Independent Variable) & & \\
\hline & Tangibility & & \\
\hline 1 & Appearance of Lecturers & 4.8850 & 0.87499 \\
\hline 2 & Layout of classrooms & 4.1300 & 1.13115 \\
\hline 3 & Lighting in classrooms & 4.5450 & 0.93399 \\
\hline 4 & Appearance of building and grounds & 4.0452 & 1.11598 \\
\hline 5 & Overall cleanliness & 3.7186 & 1.17688 \\
\hline 6 & Degree to which classrooms and study rooms are comfortable & 4.0150 & 1.06322 \\
\hline 7 & Decoration and atmosphere & 3.8700 & 1.13558 \\
\hline 8 & Appearance of personnel & 4.2350 & 1.12521 \\
\hline 9 & Available of parking & 3.6566 & 1.38638 \\
\hline 10 & The degree to which curriculum is up to date & 4.1005 & 1.04927 \\
\hline 11 & Number of courses offered & 4.3131 & 0.94677 \\
\hline 12 & Computers adequacy provided in the lab for students & 3.2650 & 1.36163 \\
\hline 13 & 'Up-to-datedness' of computers & 3.3800 & 1.36562 \\
\hline 14 & 'Up-to-datedness' of software used in computers & 3.4824 & 1.26269 \\
\hline 15 & Access to the Internet/e-mail & 3.5550 & 1.23475 \\
\hline \multirow[t]{2}{*}{16} & The organizational culture, belief and value in this university & 4.0408 & 1.03694 \\
\hline & Assurance & & \\
\hline 17 & Friendly and courteous university staffs & 4.1809 & 1.11348 \\
\hline 18 & Friendly and courteous lecturers & 4.7626 & 1.00719 \\
\hline 19 & Lecturers research efficiency/productivity & 4.5900 & 0.88647 \\
\hline 20 & Academic credentials of lecturers & 4.7700 & 0.92269 \\
\hline 21 & Lecturers are innovative and agents of change & 4.5377 & 0.90305 \\
\hline 22 & The degree to which university involve with the community & 4.2727 & 0.90305 \\
\hline 23 & University's staffs knowledge on rules and procedures & 4.3266 & 0.98926 \\
\hline 24 & Security measures at your university & 4.1364 & 1.05993 \\
\hline \multirow[t]{2}{*}{25} & $\begin{array}{l}\text { Communication skills: courses are well taught by the lecturers in this } \\
\text { university }\end{array}$ & 4.4400 & 0.86611 \\
\hline & Reliability & & \\
\hline 26 & Registration is timely and error-free & 3.5228 & 1.27204 \\
\hline 27 & This university keeps its records accurately & 3.8878 & 1.16692 \\
\hline 28 & The general reliability of lecturers ie. keeps time/don't cancel classes & 4.3550 & 1.06991 \\
\hline 29 & Staff sincere interest in solving student's problem & 3.9000 & 1.30326 \\
\hline 30 & This university provides its services at a time it promises to do so & 3.8100 & 1.03889 \\
\hline 31 & Teaching capability of lecturers/proficiency & 4.3150 & 0.96978 \\
\hline \multirow[t]{2}{*}{32} & Lecturers sincere interest in solving student's problem & 4.1106 & 1.09075 \\
\hline & Responsiveness & & \\
\hline 33 & Availability of personnel to assist you & 3.9850 & 1.07730 \\
\hline
\end{tabular}




\begin{tabular}{|l|l|l|l|}
\hline 34 & Availability of lecturers to assist you & 4.5381 & 0.97144 \\
\hline 35 & Lecturers capacity to solve problems when they arise & 4.4600 & 1.07899 \\
\hline 36 & Staffs capacity to solve problems when they arise & 4.0253 & 1.11945 \\
\hline 37 & $\begin{array}{l}\text { I seldom get the 'run-around" when seeking information on this } \\
\text { University }\end{array}$ & 3.9250 & 1.18168 \\
\hline 38 & Channels for expressing student complaints are readily available & 3.8300 & 1.11684 \\
\hline 39 & Queries are dealt with efficiently and promptly & 3.8593 & 1.26742 \\
\hline 40 & Empathy & Administration has students' best interest at heart & \\
\hline 41 & Access to computer facilities is accommodate with students' convenient & 3.7300 & 1.18990 \\
\hline 42 & Access to study rooms is accommodate with students' convenient & 3.9500 & 1.22253 \\
\hline 43 & Staff are willing to give students individual attention & 3.8200 & 1.11075 \\
\hline 44 & $\begin{array}{l}\text { The extent to which lecturers are sympathetic and supportive to the } \\
\text { needs of students }\end{array}$ & 4.4322 & 0.87281 \\
\hline 45 & Opening hour of computer rooms to the students & 3.8550 & 1.25773 \\
\hline 46 & University are fair and unbiased in their treatment of individuals students & 4.0500 & 1.11522 \\
\hline & Student Satisfaction (Dependent Variable) & & \\
\hline 1 & I am satisfied with my decision to attend this University & 4.3166 & 0.99254 \\
\hline 2 & If have a choice to do it all over again, I still will enroll in this University & 3.9397 & 1.17051 \\
\hline 3 & My choice to enroll in this University is a wise one & 4.1350 & 1.04990 \\
\hline 4 & I am happy on my decision to enroll in this University & 4.2400 & 1.03817 \\
\hline 5 & I did the right decision when I decided to enroll in this University & 4.1750 & 1.08641 \\
\hline 6 & I am happy that I enrolled in this University & 4.2100 & 1.09172 \\
\hline
\end{tabular}

Table 1.4 Reliability Results

\begin{tabular}{|l|l|l|l|l|}
\hline Variable Type & Variable Name & No. of item & Actual Test $(\alpha)$ & Mahiah. S. \\
\hline Dependent & Student Satisfaction & 6 & 0.938 & \\
\hline Independent & & & & \\
Service Quality & & & & \\
X1 & Tangibility & 16 & 0.908 & 0.851 \\
X2 & Assurance & 9 & 0.887 & 0.917 \\
X3 & Reliability & 7 & 0.874 & 0.889 \\
X4 & Responsiveness & 7 & 0.854 & 0.919 \\
X5 & Empathy & 7 & 0.881 & 0.886 \\
\hline
\end{tabular}


Table 1.5 Correlation Results

\begin{tabular}{|c|c|c|c|c|c|c|c|}
\hline Variable Type & $\mathrm{Y}$ & $\mathrm{X} 1$ & $\mathrm{X} 2$ & $\mathrm{X} 3$ & $\mathrm{X} 4$ & $\mathrm{X} 5$ & X6 \\
\hline \multicolumn{8}{|l|}{ Dependent } \\
\hline$Y=$ Satisfaction & 1.00 & & & & & & \\
\hline \multicolumn{8}{|l|}{ Independent } \\
\hline X1-Tangibility & $0.568 * *$ & 1.00 & & & & & \\
\hline X2-Assurance & $0.582 * *$ & $0.699 * *$ & 1.00 & & & & \\
\hline X3-Reliability & $0.555^{* *}$ & $0.728 * *$ & $0.789 * *$ & 1.00 & & & \\
\hline X4-Responsiveness & $0.556 * *$ & $0.669 * *$ & $0.776^{* *}$ & $0.847 * *$ & 1.00 & & \\
\hline X5-Empathy & $0.640 * *$ & $0.688 * *$ & $0.623 * *$ & $0.763 * *$ & $0.747 * *$ & 1.00 & \\
\hline X6-Overall Quality & $0.653 * *$ & $0.899 * *$ & $0.867 * *$ & $0.914 * *$ & $0.885 * *$ & $0.849 * *$ & 1.00 \\
\hline
\end{tabular}

Table 1.6 Regression Results

\begin{tabular}{|l|l|l|l|l|l|}
\hline Table & 1.6. & Regression & Results & Table & 1.6. \\
\hline Table & 1.6. & Regression & Results & Table & 1.6. \\
\hline Table & 1.6. & Regression & Results & Table & 1.6. \\
\hline Table & 1.6. & Regression & Results & Table & 1.6. \\
\hline Table & 1.6. & Regression & Results & Table & 1.6. \\
\hline Table & 1.6. & Regression & Results & Table & 1.6. \\
\hline Table & 1.6. & Regression & Results & Table & 1.6. \\
\hline
\end{tabular}

$\mathrm{R}=0.689$

$\mathrm{R} 2=0.475$

Adjusted R2 $=0.459$

F Change $=29.102 \quad$ Sig. $F=0.000 \quad N=200$

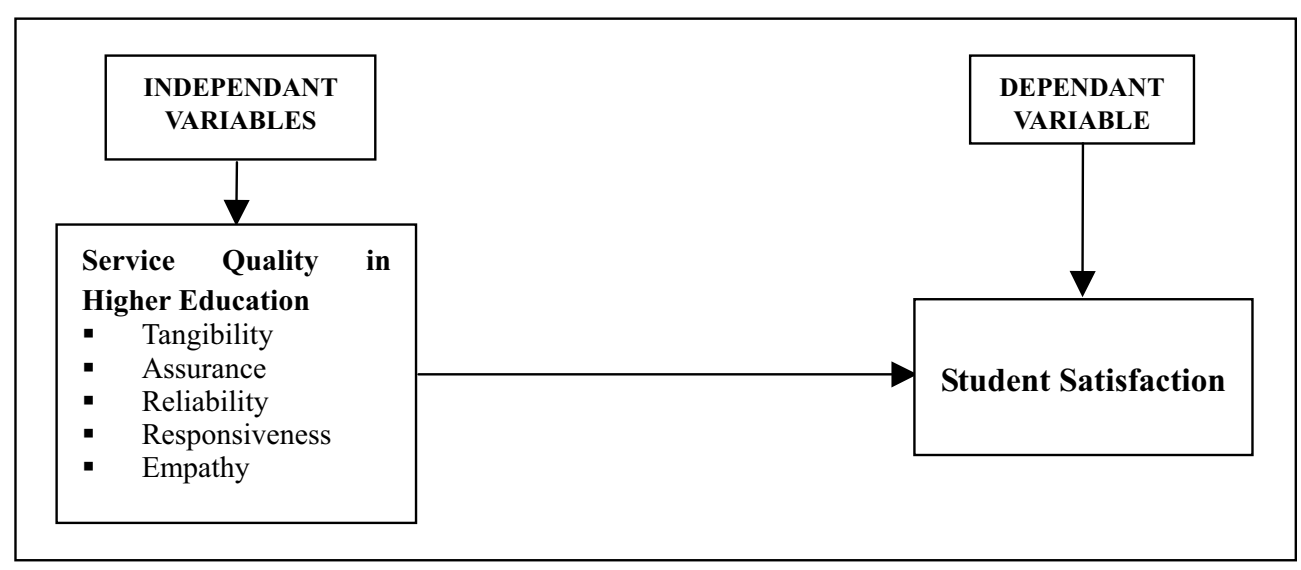

Figure 3.1 Research Framework 